\section{Established 'Tifblue' Rabbiteye Blueberries Respond to Irrigation and Fertilization}

\author{
James M. Spiers ${ }^{1}$ \\ U.S. Department of Agriculture, Agricultural Research Service, Small Fruit \\ Research Station, P.O. Box 287, Poplarville, MS 39470
}

Additional index words. Vaccinium ashei

\begin{abstract}
The effects of varying rates of a complete fertilizer and irrigation on the growth and fruit yields of 'Tifblue' rabbiteye blueberries (Vaccinium ashei Reade) established 3 years before treatment initiation were determined in a field study. Increased rates of irrigation resulted in increased plant growth and fruit yields. Five- and 6-year-old plants were more responsive to increasing irrigation rates than older plants. Irrigation water efficacy was greatest at lower rates and progressively less at higher rates of irrigation. Fiveand 6-year-old plants fertilized with the lowest rate $(14 \mathrm{~N}-4 \mathrm{P}-7 \mathrm{~K} ; 150 \mathrm{~g} /$ plant $)$ grew and yielded less than those fertilized with higher rates. Older plants did not respond to fertilization rates higher than $150 \mathrm{~g} /$ plant. Yearly rates of fertilization above $300 \mathrm{~g} / \mathrm{plant}$ did not influence plant growth or fruit yields. Fertilization and irrigation responses were independent.
\end{abstract}

Rabbiteye blueberries are usually grown on well-drained upland soils with low nutrient and water-holding capacities and low organic matter content. Early and continued optimum fruit production depends on successful establishment and first-year growth of the plant. Cultural practices, such as incorporating organic matter in the planting hole, mulching, and irrigation, improve the soil moisture condition and enhance growth and yield of rabbiteye blueberries (Brightwell, 1971; Moore, 1971; Spiers, 1983).

Young rabbiteye blueberry plants are very sensitive to fertilizer (Austin and Mullinix, 1980; Brightwell, 1971; Moore, 1971) and overfertilization can cause severe damage (Austin and Brightwell, 1977). First- and second-year plant growth and second-year fruit yields of rabbiteye blueberries were reduced by either slow-release or fast-release granulated fertilizer (Spiers, 1982). Soluble fertilizers produced less plant damage than granulated fertilizers but no more plant growth than lack of fertilization. There was a close association between overfertilization and chlorosis. Field studies in Georgia over several years showed little or no growth response of rabbiteye blueberries to fertilization (Austin and Brightwell, 1977). In Mississippi, rabbiteye blueberries grown in the field for 4 years showed no positive plant growth or fruit yield responses to various fertilizer sources or rates higher than $40 \mathrm{~g} /$ plant of a complete fertilizer (Spiers, 1987).

Received for publication 15 Feb. 1996. Accepted for publication 27 Aug. 1996. The cost of publishing this paper was defrayed in part by the payment of page charges. Under postal regulations, this paper therefore must be hereby marked advertisement solely to indicate this fact.

${ }^{1}$ Research Horticulturist.
This study was conducted to determine the effects of irrigation and fertilizer rates applied to established rabbiteye blueberry plants.

\section{Materials and Methods}

Two-year-old, bare-rooted 'Tifblue' rabbiteye blueberry plants were set in Spring 1983 on a Ruston fine sandy loam soil (fineloamy, siliceous, thermic Typic paleudult) with peat $(10 \mathrm{~L} /$ plant $)$ incorporated in the planting hole. Plant spacing was $1.8 \times 3.7 \mathrm{~m}$. This soil has a cation exchange capacity of $6.2 \mathrm{meq} / 100$ $\mathrm{g}$ and a soil $\mathrm{pH}\left(1\right.$ soil : $\left.2 \mathrm{H}_{2} \mathrm{O}\right)$ of 5.2. Available soil (0 to $15 \mathrm{~cm}$ depth) macronutrients averaged (in kg.ha ${ }^{-1}$ ): N, 44; P, 74; K, 58; Mg, 82; $\mathrm{Ca}, 312$; and $\mathrm{S}, 133$, as determined by the Soil Testing Laboratory, Mississippi State Univ. Plants were grown uniformly for 3 years with irrigation applied on an as-needed basis. Pretreatment fertilization consisted of no fertilizer in 1983, then a single 50-g application in 1984 and two 50-g applications of $14 \mathrm{~N}-4 \mathrm{P}-$ $7 \mathrm{~K}$ per plant in 1985 . Rainfall over the entire study period averaged $1600 \mathrm{~mm}$ annually.

Fertilizer and irrigation treatments were started in Apr. 1986 and arranged as a $4 \times 4$ factorial in a split-plot design with four replications. Fertilizer [14N-4P-7K with $\mathrm{N}$ as $\left(\mathrm{NH}_{4}\right)_{2} \mathrm{SO}_{4}$ ] levels (subplots) included 150 (three 50-g bimonthly applications), 300 (six 50 -g monthly applications), 600 (six 100-g monthly applications), and $1200 \mathrm{~g}$ (six 200-g monthly applications) per plant annually. Fertilizer was broadcast in a $1-\mathrm{m}^{2}$ area around each plant crown and applied from 1986 through 1992. Irrigation (drip with two emitters per plant) treatments (whole plots) were $3.3,6.6,13.2,26.5 \mathrm{~L} \cdot$ week $^{-1}$ applied in two equal amounts weekly from April to October annually, regardless of rainfall.

Total fruit yield (1988-92) and plant height and volume (1986-92) were measured annually. Floral bud development ratings (Spiers,
1978) were taken 16 Mar. 1988, 1 Mar. 1989, and 20 Feb. 1990. Standard and regression analyses of variance and correlations were conducted using SAS (SAS Institute, 1992).

\section{Results and Discussion}

Plant height increased steadily with increasing irrigation levels during the first 2 years of measurement, but by 1989 this trend had leveled off at around $13.2 \mathrm{~L} \cdot$ week $^{-1}($ Table 1). Plant height was not influenced by fertilization until 1988 when it leveled off around $300 \mathrm{~g} /$ plant with heights of $119,145,146$, and $138 \mathrm{~cm}$ with fertilizer rates of $150,300,600$, and $1200 \mathrm{~g} / \mathrm{plant}$, respectively (LQ $\leq 0.05$ ), were recorded (detailed data not shown). However, fertilizer levels did not influence plant height in subsequent years.

The interaction between fertilizer and irrigation levels was significant for plant height in 1992 (not shown). That year, plant height increased about the same, regardless of treatments, except on plants receiving the lowest irrigation and the highest fertilization rates. These plants grew significantly less in height than plants receiving the highest fertilization rate and any other irrigation treatment. This result was not evident in plant height any other year. Plant volume was highly correlated with plant height $(P<0.001)$ (data not shown).

From 1989 to 1992, fruit yield increased steadily with increasing irrigation (Table 2). This trend also was reflected in the 5-year total for 1988-92. Plants irrigated with $26.4 \mathrm{~L}$ week ${ }^{-1}$ averaged $\approx 2.2 \mathrm{~kg}$ more fruit production annually than those irrigated with $3.3 \mathrm{~L} \cdot$ week $^{-1}$. With an average of 1500 plants/ha, this difference would result in a gain in fruit yield of $\approx 3300 \mathrm{~kg} \cdot \mathrm{ha}^{-1}$ annually. Plants irrigated with $26.4 \mathrm{~L} \cdot$ week $^{-1}$ produced an annual average of $\approx 0.5 \mathrm{~kg}$ more fruit/plant than those irrigated with $13.2 \mathrm{~L} \cdot$ week $^{-1}\left(\approx 750 \mathrm{~kg} \cdot \mathrm{ha}^{-1}\right)$. Per plant fruit yield increases due to irrigation were highest when irrigation rates were increased from 3.3 to $6.6 \mathrm{~L} \cdot$ week $^{-1}$, and less when rates were from 6.6 to 13.2 and 13.2 to $26.4{\mathrm{~L} \cdot \text { week }^{-1}}^{-1}$ (1.8, 0.4, and $0.2 \mathrm{~kg}$ fruit/L, respectively). In 1988 and 1989, fruit yield peaked in plants receiving $600 \mathrm{~g}$ of fertilizer. After 1989, fertilizer levels did not influence yield and the 5year total showed no significant trends.

Response of plant volume to irrigation and fertilization followed the same general pattern as plant height (data not shown). Plant volume and plant height were highly correlated with fruit yields $(P<0.001)$. Over the study, plant height and plant volume were highly correlated with each other but plant height was more highly correlated to fruit yield than was plant volume.

Overall, increasing either irrigation or fertilization levels resulted in more advanced stages of floral development (Table 3). Rate of flower development increased with increased irrigation, although increases were always small. Up to $600 \mathrm{~g} /$ plant, floral development tended to be more advanced with higher levels of fertilizer in 2 of 3 years.

Established 'Tifblue' plants responded positively to irrigation regardless of fertiliza- 
Soll Management, Fertilization, \& Irrigation

Table 1. Influence of irrigation applied per plant on height of 'Tifblue' blueberry plants.

\begin{tabular}{|c|c|c|c|c|c|c|c|}
\hline \multirow{2}{*}{$\begin{array}{l}\text { Irrigation } \\
\left(\mathrm{L} \cdot \text { week }^{-1}\right)\end{array}$} & \multicolumn{7}{|c|}{ Plant ht $(\mathrm{cm})$} \\
\hline & 1986 & 1987 & 1988 & 1989 & 1990 & 1991 & 1992 \\
\hline 3.3 & 71 & 103 & 125 & 149 & 173 & 188 & 223 \\
\hline 6.6 & 78 & 122 & 139 & 171 & 195 & 201 & 240 \\
\hline 13.2 & 76 & 121 & 143 & 176 & 211 & 218 & 254 \\
\hline 26.4 & 87 & 128 & 141 & 180 & 212 & 216 & 249 \\
\hline Linear & $*$ & * & NS & $* *$ & $* * *$ & $* *$ & $*$ \\
\hline Quadratic & NS & NS & NS & $*$ & $* *$ & $*$ & $*$ \\
\hline
\end{tabular}

Ns, ${ }^{*}, *, * * *$ Nonsignificant and significant at $P \leq 0.05,0.01$, or 0.001 , respectively.

Table 2. Influence of irrigation and fertilizer levels applied per plant on fruit yield of 'Tifblue' blueberry plants.

\begin{tabular}{|c|c|c|c|c|c|c|}
\hline \multirow[b]{2}{*}{ Variable } & \multicolumn{6}{|c|}{$\begin{array}{c}\text { Fruit yield } \\
\text { (kg/plant) }\end{array}$} \\
\hline & 1988 & 1989 & 1990 & 1991 & 1992 & Total \\
\hline \multicolumn{7}{|c|}{ Irrigation $\left(\mathrm{L} \cdot \mathrm{week}^{-1}\right)$} \\
\hline 3.3 & 2.36 & 2.15 & 6.23 & 5.78 & 7.18 & 23.25 \\
\hline 6.6 & 2.64 & 2.96 & 7.24 & 7.44 & 8.86 & 29.14 \\
\hline 13.2 & 3.37 & 3.60 & 8.20 & 6.79 & 9.79 & 31.74 \\
\hline 26.4 & 3.23 & 4.04 & 9.02 & 8.06 & 9.80 & 34.15 \\
\hline Linear & NS & $* * *$ & $* * *$ & $*$ & $*$ & $* * *$ \\
\hline Quadratic & NS & NS & NS & NS & NS & NS \\
\hline \multicolumn{7}{|c|}{ Fertilization (g/plant) } \\
\hline 150 & 1.33 & 2.23 & 6.85 & 6.82 & 8.99 & 25.65 \\
\hline 300 & 3.28 & 3.12 & 8.32 & 7.03 & 9.79 & 31.54 \\
\hline 600 & 3.68 & 3.82 & 8.21 & 7.37 & 8.40 & 31.48 \\
\hline 1200 & 3.30 & 3.59 & 7.31 & 6.85 & 8.56 & 29.61 \\
\hline Linear & $* *$ & $*$ & NS & NS & NS & NS \\
\hline Quadratic & $* * *$ & * & NS & NS & NS & NS \\
\hline
\end{tabular}

ss, $, * *, * * * *$ Nonsignificant and significant at $P \leq 0.05,0.01$, or 0.001 respectively.

tion levels. Plants established for 5 to 7 years responded more to increased irrigation rates than older plants. Irrigation water usage was more efficient at lower rates of irrigation and became progressively less efficient as irrigation was increased. Plants established for 3 or more years were less sensitive to high rates of fertilization than younger or newly established plants. These plants could be fertilized with a complete fertilizer at rates up to $1200 \mathrm{~g} / \mathrm{plant}$ annually without eliciting phytotoxicity symp-

toms when single applications did not exceed $200 \mathrm{~g} / \mathrm{month}$. However, annual fertilizer application exceeding $300 \mathrm{~g} / \mathrm{plant}$ was not beneficial.

\section{Literature Cited}

Austin, M.E. and W.T. Brightwell. 1977. Effect of fertilizer applications on yield of rabbiteye blueberries. J. Amer. Soc. Hort. Sci. 102:36-39.

Austin, M.E. and B.G. Mullinix. 1980. Plant populations and fertility studies on rabbiteye blueber-
Table 3. Influence of irrigation and fertilizer levels applied per plant on floral bud ratings of 'Tifblue' blueberry.

\begin{tabular}{lccc}
\hline \hline & \multicolumn{3}{c}{ Visual floral bud ratings } \\
\cline { 2 - 4 } Variable & 1988 & 1989 & 1990 \\
\hline Irrigation $\left({\left.\mathrm{L} \cdot \text { week }^{-1}\right)}^{-1}\right.$ & & & \\
3.3 & 3.8 & 3.5 & 2.9 \\
6.6 & 3.8 & 3.4 & 3.2 \\
13.2 & 4.1 & 3.8 & 3.6 \\
26.4 & 4.1 & 3.9 & 3.6 \\
Linear & $*$ & $*$ & $* *$ \\
Quadratic & NS & NS & NS \\
Fertilization (g/plant) & & & \\
150 & 3.6 & 3.3 & 3.1 \\
300 & 3.9 & 3.4 & 3.4 \\
600 & 4.3 & 3.9 & 3.3 \\
1200 & 4.1 & 3.9 & 3.3 \\
Linear & $*$ & $* *$ & NS \\
Quadratic & $*$ & NS & NS \\
\hline
\end{tabular}

${ }^{\mathrm{z}} 1=$ no visible bud swelling; $7=$ corollas dropped. Ns, ${ }^{*},{ }^{* *}$ Nonsignificant and significant at $P \leq 0.05$ or 0.01 , respectively.

ries. J. Amer. Soc. Hort. Sci. 102:36-39.

Brightwell, W. T. 1971. Rabbiteye blueberries. Georgia. Agr. Expt. Sta., Res. Bul. 100.

Moore, J. N. 1971. Blueberry variety performance in Arkansas. Univ. of Arkansas Agr. Expt. Sta. Rpt. Ser. 186.

SAS Institute. 1992. User's guide, release ed. 6.03. SAS Inst., Cary, N.C.

Spiers, J.M. 1978. Effect of stage of bud development on cold injury in rabbiteye blueberry. J. Amer. Soc. Hort. Sci. 103:452-455.
Spiers, J.M. 1982. Fertilization, incorporated organic matter, and early growth of rabbiteye blueberries. J. Amer. Soc. Hort. Sci. 107:10541058.

Spiers, J.M. 1983. Influence of N, K, and Na concentration on growth and leaf element content of 'Tifblue' rabbiteye blueberry. HortScience 18:223-224.

Spiers, J.M. 1987. Effect of fertilization rates and sources on rabbiteye blueberry. J. Amer. Soc. Hort. Sci. 112:600-603. 